\title{
Anti-Proliferative Activity and Apoptosis Induction of an Ethanolic Extract of Boesenbergia pandurata (Roxb.) Schlecht. against HeLa and Vero Cell Lines
}

\author{
Shanti Listyawati ${ }^{1,2}$, Sismindari ${ }^{3 *}$, Sofia Mubarika ${ }^{4}$, Yosi Bayu Murti ${ }^{3}$, Muthi \\ Ikawati $^{3}$
}

\begin{abstract}
Rhizomes of Boesenbergia pandurata (Roxb.) Schlecht have been reported to contain active compounds with anticancer properties. This research was carried out to examine anti-proliferative and apoptotic induction against HeLa and Vero cells-line. Dried powder of $B$. pandurata rhizomes was extracted by a maceration method using 90\% ethanol. Cytotoxic assays to determine $\mathrm{IC}_{50}$ and anti-proliferative effects were carried out by MTT methods. Observation of apoptosis was achieved with double staining using acridine orange and ethidium bromide. The results showed that ethanolic extract of $B$. pandurata was more cytotoxic against HeLa cells $\left(\mathrm{IC}_{50}\right.$ of $60 \mu \mathrm{g} /$ $\mathrm{mL})$ than Vero cells $\left(\mathrm{IC}_{50}\right.$ of $\left.125 \mu \mathrm{g} / \mathrm{mL}\right)$. The extract had higher anti-proliferative activity as well as apoptotic induction in HeLa than Vero cells. Therefore, it was concluded that the ethanolic extract of B. pandurata had anti-proliferative as well as apoptosis induction activity dependent on the cell type.
\end{abstract}

Keywords: Boesenbergia pandurata - anti-proliferative activity - apoptosis - Hela cells - Vero cells

Asian Pac J Cancer Prev, 17 (1), 183-187

\section{Introduction}

Natural products may serve as a source of many phytochemicals that possess various bioactivities including to prevent cancer, cardiovascular disease, infection and inflammation (Rabeta et al., 2013; Palasap et al., 2014). Therefore, it is promising to discover anticancer compounds from natural product. Boesenbergia pandurata (Roxb.) Schlecht.), known as temu kunci in Indonesia and krachai in Thailand, is one of the edible plants on the ginger family (zingiberaceae) that distributed in Southeastern Asian such as Indonesia, Thailand, and Malaysia. The rhizome has been used tradisionaly for a spice and folk medicine such as treatment of inflammation and gastrointestinal disorder (Kementrian Kesehatan Republik Indonesia, 2010)

Several studies on the rhizomes extract of $B$. pandurata and their isolated compounds have showed some pharmacological activities. The ethanol extracts of this rhizome showed high cytotoxic activity against the Hep2 cell-lines (Kamkaen et al., 2006), and the methanol extract showed an anti-proliferative effect against ovarian (CaOV3), breast (MDA-MB-231 and MCF-7), cervical (HeLa) and colon (HT-29) cancer celllines (Jing et al., 2010). The rhizome contains bioactive compounds such as pinostrobin, pinocembrin, alpinetin, cardamomin, boesenbergin A, panduratin A and rubranin
(Yun et al., 2006; Ching et al., 2007; Tanjung et al., 2013). Boesenbergin A isolated from Boesenbergia rotunda, a chalcone has been found as anti-cancer effect through the induction of apoptosis against human non-small cell lung cancer (A549 cells) (Isa, et al., 2013). Panduratin A, a cyclohexenyl chalcone derivative, showed antiproliferative effect and induced apoptosis on human breast cancer (MCF-7) and human colon adenocarcinoma (HT29) cell-lines (Kirana et al., 2007). In addition, panduratin A also found to inhibit the angiogenesis process at in-vitro and in-vivo levels (Lai, et al., 2012). Hydroxypanduratin A and panduratin A showed anti-inflamatory activity on the TPA-induced ear edema assays in rats (Tuchinda et al., 2002) and murine macrophage-like RAW 264.7 cells-line through inhibition of PGE2 and TNF- $\alpha$ release (Tewtrakul et al., 2009). Both compounds also showed good competitive inhibitory activities towards dengue 2 virus NS3 protease (Kiat et al, 2006). Major antioksidan activity was also showed on hydroxypanduratin $\mathrm{A}$ and panduratin A, through the inhibitory activities of rat brain lipid peroxidation (Shindo et al., 2006). Pinocembrin and pinostrobin, flavanones isolated Kaemferia pandurata showed antioxidant and cytotoxic activity (Tanjung et al., 2013).

All the activity of these substances isolated from B. pandurata, antioxidant, anti-inflammation, antimutagenic, and anti-angiogenesis (Shindo et al., 2006; 
Shanti Listyawati et al

Kirana et al., 2007; Morikawa et al., 2008; Tewtrakul et al., 2009) are associated with chemoprevention activity. Therefore, it is needed to investigate the antiproliferative and apoptosis effects of the rhizome extract of B. pandurata grown at Yogyakarta against HeLa and Vero cells.

\section{Materials and Methods}

\section{Plant material}

Rhizomes of $B$. pandurata were collected from Kalibawang, Kulonprogo, Yogyakarta, Indonesia, and was determinated by Pharmaceutical Biology Department, Faculty of Pharmacy, Universitas Gadjah Mada. This rhizome was sliced and dried at $50^{\circ} \mathrm{C}$ then grounded to a fine powder. Extract was prepared by maceration method using 90\% ethanol and then evaporated Semisolid extract was quantified by TLC scanner using pinostrobin as an active marker. This extract was reffered as EEBP.

\section{Cell culture}

HeLa cell-lines (human cervical cancer) and Vero celllines (normal cells of African green monkey kidney) were obtained from Life Science Laboratory, LPPT UGM. Cells was grown in RPMI1640 (Gibco) medium supplemented with $10 \%$ fetal bovine serum (FBS, Gibco) and $1 \%$ Penisilin - Streptomisin (Gibco) at $37^{\circ} \mathrm{C}$ with $5 \% \mathrm{CO}_{2}$.

\section{Cytotoxic assay}

The cytotoxicity was determined by MTT assay. HeLa and Vero cells at density of $10^{5}$ cells $/ \mathrm{mL}$ were distributed into 96 wells of plates, treated with various concentration of B. pandurata extracts dissolved in dimethylsulphoxide (DMSO 1,952 - $1000 \mu \mathrm{g} / \mathrm{mL}$ ), followed by incubation for $24 \mathrm{hr}$. Each well was added by $15 \mu 10.3 \%$ MTT in PBS, and after $6 \mathrm{~h}$ the reaction was stopped by $10 \%$ SDS. The formation of purple phormazan crystal was identified by ELISA reader at $550 \mathrm{~nm}$. The $\mathrm{IC}_{50}$ was determinate, as concentration of the extraxt required that inhibit of $50 \%$ cells growth (Doyle and Griffiths, 2000).

\section{Anti-proliferative assay}

HeLa and Vero cell $\left(2 \times 10^{4}\right) / \mathrm{mL}$ was grown and starvated in culture media (DMEM) with $0.5 \%$ FBS for $24 \mathrm{hr}$ in 96 wells plate, and added with B.pandurata extract at a concentration of $7.5,15$, and $30 \mathrm{ug} / \mathrm{ml}$ in DMSO. The viability of cells was assessed by MTT assay. Population of viable cells in each group treatment was evaluated at 24,48 , and $72 \mathrm{~h}$.

\section{Induction of apoptosis assay}

Cells $\left(5 \times 10^{4}\right) /$ well were grown in cover slip at 24 wells plates, treated with $B$. pandurata extract at a dose of $\mathrm{IC}_{50}$ and incubated for $24 \mathrm{hr}$. The cell was rinsed by PBS and added $10 \mu \mathrm{L}$ ethidium bromide-acridine orange $(5 \mu \mathrm{g} / \mathrm{mL}$ in PBS/well). The cells were evaluated by fluorescent microscope $400 \mathrm{X}$. The apoptosis was defined as the appearance of apoptotic bodies, cytoplasmic changes, and chromatin condensation. The dead cells were showed at orange color, and survived cells were green.

\section{Statistical analysis}

Absorbance value from cytotoxic and inhibition of proliferation converse to viability cell (\%).

$\% \%$ viable cells $=$

$\frac{\text { absorbance of cells-absorbance of medium control }}{\text { absorbance of cells medium control - absorbance of medium control }} \times 100$

Numerical data for treatment cells was subjected to ANOVA analysis. Significance of differences among treatment on the cells was determined by Tukey's test used SPSS statistical package (version 17.0). The $\mathrm{p}<0.05$ were considered as statistically significant.

\section{Results}

Cytotoxic activity of ethanolic extract of B. pandurata rhizomes

Cytotoxic test was done to find out the potency of B. pandurata extract against growth inhibition of HeLa cells-line and Vero cells-line as a normal control. The cytotoxic result indicated that different concentration of $B$. pandurata extract $(0,16,31,63,125$ and $250 \mu \mathrm{g} /$ $\mathrm{mL}$ ) affected on cells viability of both HeLa and Vero cells-line for $24 \mathrm{~h}$ at different level (Figure 1). The higher concentration of $B$. pandurata extract resulted on the reduction of cells viability. $B$. pandurata extract had less cytotoxic against Vero cells, a normal control, compared to HeLa cells-line, with the $\mathrm{IC}_{50}$ of $125 \mu \mathrm{g} / \mathrm{mL}$ and $56 \mu \mathrm{g} /$ $\mathrm{mL}$, respectivelly. It appeared that the extract was more sensitive to HeLa cells than Vero cells.

Anti-proliferative activity of ethanolic extract of $B$.

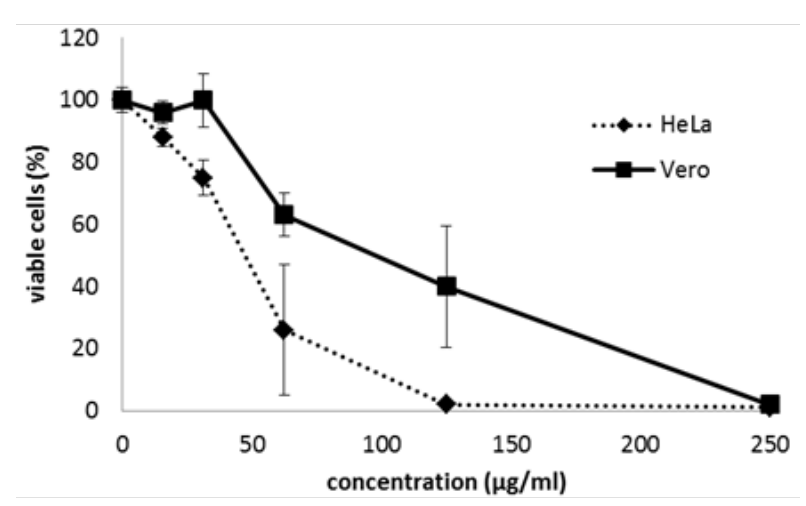

Figure 1. The cytotoxic effect of $B$. pandurata extract on HeLa and Vero Cells at 24 hours incubation. HeLa and Vero cells were treated with B.pandurata extract at different concentration from $16 \mu \mathrm{g} / \mathrm{mL}$ to $250 \mu \mathrm{g} / \mathrm{mL}$ for 24 hours. Data was expressed as mean $\pm \mathrm{SD}(\mathrm{n}=3)$

Table 1. Effect of EEBP Against Apoptosis of HeLa and Vero Cells

\begin{tabular}{ccc}
\hline No. & Groups & Apoptotic cells $(\%)$ \\
\hline 1 & HeLa + EEBP & $43.5 * \pm 3.4$ \\
2 & HeLa tanpa EEBP & $15.6 \pm 2.8$ \\
3 & Vero + EEBP & $14.6 \pm 2.1$ \\
4 & Vero tanpa EEBP & $15.2 \pm 2.2$ \\
\hline
\end{tabular}

*Significantly different $p<0.05$ 

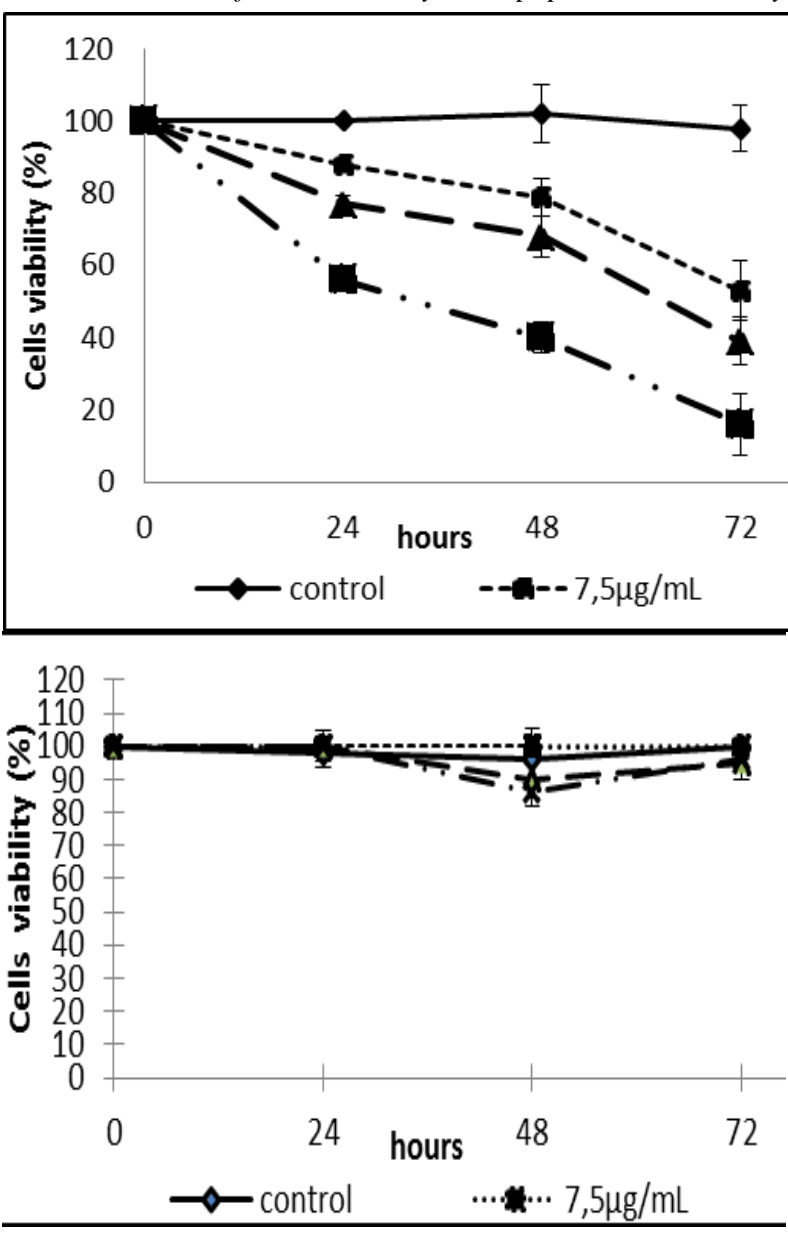

Figure 2. Effect of ethanolic extract $B$. pandurata against HeLa (A) and Vero (B) cells-lines growth. Cells were treated with $7.5,15$, and $30 \mu \mathrm{g} / \mathrm{mL}$ of ethanolic extract B. pandurata for 24,48 , and 72 hours, and cell viability was determined by MTT assay. The data represents the mean \pm SD of three independent experiments with triplicate in measurements

\section{pandurata rhizomes}

Anti-proliferative assay rhizome $B$. pandurata extract against HeLa and Vero cell-lines was done by doublingtime assay, and used concentration around $\mathrm{IC}_{50}$ result, that were $0 ; 7,5 ; 15 ;$ and $30 \mu \mathrm{g} / \mathrm{mL}$. The result showed that the extract could stronger inhibits the proliferation of HeLa cell at 24, 48, and 72 hours (Figure 2A), than Vero cells (Figure 2B). Increasing extract concentration could increase the inhibition of cells proliferation. The extracts could inhibit HeLa cells proliferation from $14 \%$ to $87 \%$. However, at the concentration of $30 \mu \mathrm{g} / \mathrm{mL}$, the extract could only inhibited $28 \%$ proliferation of Vero cells.

\section{Induction of apoptosis}

Apoptosis assay was done by double staining using ethidium bromide-orange acridine. It was demonstrated that at the extract concentration of $30 \mu \mathrm{g} / \mathrm{mL}$ caused the formation of apoptotic body as shown by the orange reddish cells on HeLa cells, this indicating the cells were undergo apoptotic process (Figure 3A). The orange reddish of the cells is caused by membrane permeability damage, so that, ethidium bromide penetrate into cells (Meiyanto et al., 2008). While in Vero cells the formation of apoptotic body was very low even at the concentration

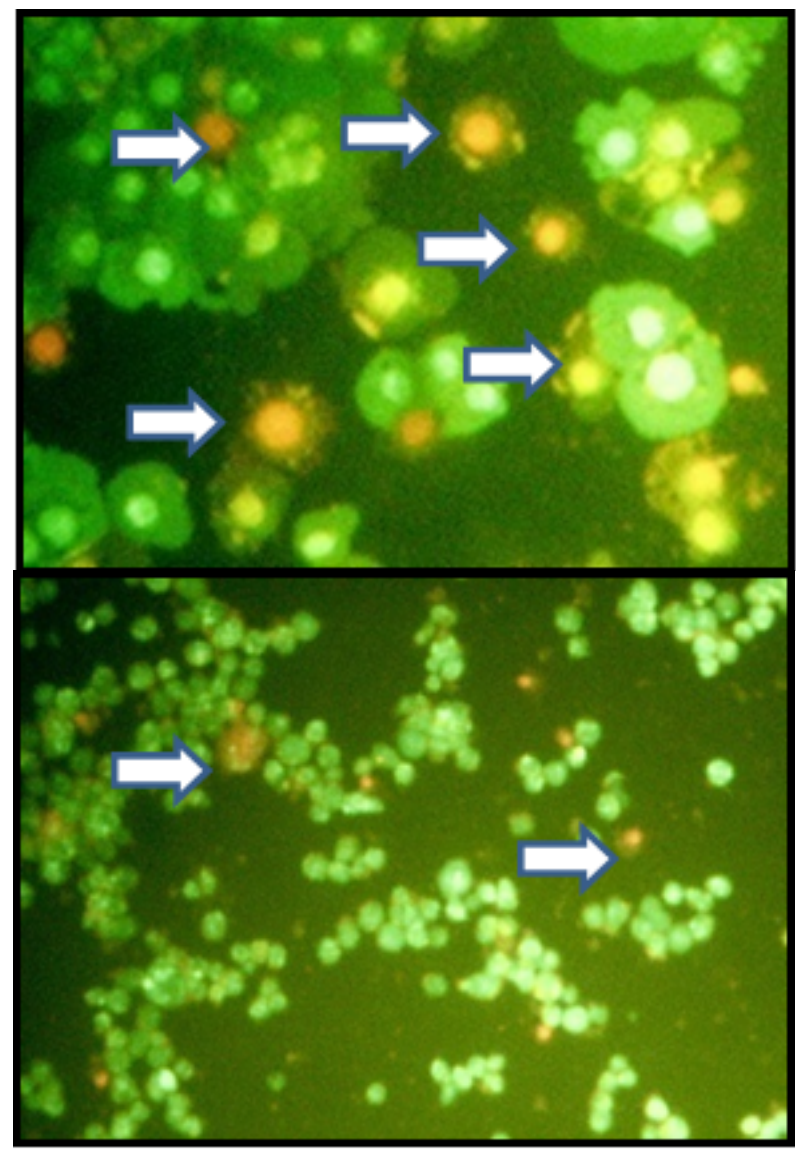

Figure 3. Double staining ethidium bromide-acridine orange of HeLa (A) and Vero (B) cell-lines. Orange fluorescence cells indicated the cells undergo to apoptosis (white arrow) (magnification 100x)

of $30 \mu \mathrm{g} / \mathrm{mL}$, indicating that apoptotic process was very low (Figure 3B). Incubation with EEBP significantly increased apoptotic HeLa cells were $28 \%$ than without EEBP. While in vero cells line, treatment EEBP didn't show significantly different with control (Tabel 1)

\section{Discussion}

The use natural products now have given of exceptional value in the control of cancer. Many chemoprevention and anti-cancer agents currently used have origin in plants (Al-oqail et al., 2013; Hussain et al., 2015). Using natural products from plants or herbs have some andvantages, having low side effect and low cost and also being easily accessible in comparison to common treatment methods, may play an important role in the treatment of the cancer (Fattahi et al., 2013) One of the plants that potentially as chemopreventife and anti-cancer agent is B. pandurata. Many studies of this edible plant showed many bioactivity including cytotoxic and apoptotic induce against cancer cells line (Kirana et al., 2006; Jing et al., 2010)

In this study, extraction of $B$. pandurata rhizomes using maseration method with $90 \%$ ethanol produced semisolid extract with pinostrobin content of $0.49 \%$. The cytotoxic activity assay of ethanolic extract of $B$. pandurata (EEBP) against HeLa cells line resulted $\mathrm{IC}_{50}$ of $56 \mu \mathrm{g} / \mathrm{mL}$. This result supported the previous study of 
finger root (Boesenbergia rotunda syn. B. pandurata) collected from Malaysia, which had the cytotoxic activity against $\mathrm{HeLa}$ cells line, with the $\mathrm{IC}_{50}$ of $65.50 \mu \mathrm{g} / \mathrm{mL}$ (Jing et al., 2010) and from Tawangmangu Indonesia was $87 \mu \mathrm{g} / \mathrm{mL}$ (Handoko et al., 2011). Differences of origin locally and extraction method of rhizomes produce different quality, quantity, and activity of extract. Many compounds also showed citotoxic activity against HeLa cells-line, such as phytophenolic from Caesalpinia mimosoides (Palasap et al., 2014) and Aloe vera crude extract $\left(\mathrm{IC}_{50}=60 \%\right)$ (Hussain et al., 2015). Compounds with the $\mathrm{IC}_{50}$ value less than $100 \mu \mathrm{g} / \mathrm{mL}$ has the potency as a cancer chemoprevention (Meiyanto, et al., 2008). Result of this study, indicated that EEBP more active on inhibiting proliferation of HeLa than Vero cells-lines, so that the extract could be used as a potent candidate for cancer chemoprevention agent. This finding related to the result of study which reported that finger root (B. rotunda) methanolic extract could inhibit proliferation of HeLa cells but not on normal cells (fibroblast cells - lines 3T3) (Jing et al. 2010). Many phytochemicals also demonstrated inhibited proliferation of HeLa cells line such as ethanol extract of bark and leaves of Erythrina fusca Lour (Meiyanto et al., 2003) and Sauromatum giganteum showed inhibition rates 6,24\% (Gao et al., 2014).

Several studies have shown that $B$. pandurata consist of some compounds, such as pinostrobin, pinocembrin, alpinetin, cardamomin, boesenbergin A, panduratin A, and rubranin (Yun et al., 2006; Ching et al., 2007). Pinocembrin and pinostrobin, flavonoid from rhizomes $B$. pandurata showed cytotoxic activity against P-388 murine leukemia cells-line (Tanjung et al., 2013). Pinostrobin was also reported could inhibite MCF-7 cell-lines (Le Bail et al., 2000). Other isolated compound, Panduratin A was also reported could inhibit HT-29 cancer cells proliferation at $\mathrm{GO} / \mathrm{G} 1$ phase (Yun et al., 2006). In addition panduratin A inhibited PC3 and DU145 cells through the inhibition of cyclin-CDK complex formation (Yun et al., 2006). Cytotoxic effect and inhibiting proliferation of EEBP against HeLa cells-line may be caused of flavonoids and chalcon which contained of EEBP such as pinostrobin, pinocembrin, and panduratin-A.

The induction of apoptosis is a hallmark of cancer treatment (Hanahan and Weinberg, 2011). Induce of cancer cells to apoptosis is one of target for cancer chemoprevention, since no inflammation is found during this process. The induction of apoptotic effect of EEBP against of HeLa cells-line was supported the previous finding on HT-9 human colon adenocarcinoma cells line treated with panduratin A isolated from $B$. pandurata rhizome by inhibition of procaspase 9, 8, 3, 6 proteins, cause apoptotic process (Yun et al., 2006). Previouse study showed that a large spectrum of chalcone derivatives with proapoptotic properties have been found in various edible or medical plants (Orlikova et al., 2011). Beside panduratin A other coumpounds, chalcone, and cardomomin, enhanced TRAIL-induced apoptosis in TRAIL-resistant DLD1 cells-line (colorectal adenocarcinoma), increased expression of death receptor (DR4 and DR5) and reduced Bcl-xL levels following cardamomin treatment of cells (Hsu et al., 2006). The apoptotic induction effect of EEBP found to be selective to cancer cells show that it could be a potent cancer chemoprevention agent.

Ethanolic extract of $B$. pandurata had more potent cytotoxic activity, inhibition of proliferation, and apoptotic induction on HeLa cells-line compare to Vero cellsline. The extracts could be as candidate agent of cancer chemoprevention.

\section{Acknowledgements}

This study was part of a doctoral thesis and financially supported by Research and Development Department of Health Ministry, Republic of Indonesia (RISBIN IPTEKDOK 2011 Program, SPK: 06/01/1/1055/2011).

\section{References}

Al-oqail MM, Farshori NN, Al-sheddi ES, et al (2013). In vitro cytotoxic activity of seed oil of fenugreek against various cancer cell lines. Asian Pac J Cancer Prev, 14, 1829-32.

Ching AYL, Wah TS, Sukari MA, et al (2007). Charactererization of flavonoid derivatives from Boesenbergia rotunda (L.). Malaysian J Anal Sci, 11, 154- 9.

Doyle A and Griffiths JB (2000). Cell and tissue culture for medical research. England: John Wiley and Sons. LTD.

Fattahi S, Ardekani AM, Zabihi E, et al (2013). Antioxidant and apoptotic effects of an aqueous extract of Urtica dioica on the MCF-7 human breast cancer cell line. Asian Pac J Cancer Prev, 14, 5317- 23.

Gao S, Li J, Wang L, Sun Q, et al (2014). Ethanol but not aqueous extracts of tubers of Sauromatum giganteum (Engl.) cusimano and hett inhibit cancer cell proliferation. Asian Pac J Cancer Prev, 15, 10613-619.

Hanahan D and Weinberg RA (2011). Hallmarks of cancer: the next generation. Cell, 144, 646-74.

Handoko FF, Maruti AA, Rivanti E, et al (2011). Cytotoxic effects of Boesenbergia pandurata ethanolic extract against cervical cancer (HeLa) and colon cancer (WiDr) cells-line. Majalah Kesehatan Pharma Medika, 1, 222-6.

Hsu YL, Kuo PL, Tzeng WS, Lin CC (2006). Chalcone inhibits the proliferation of human breast cancer cell by blocking cell cycle progression and inducing apoptosis. Food Chem Toxicol, 44, 704- 13.

Isa NM, Abdul AB, Abdelwahab, et al (2013). Boesenbergin A, a chalcone from Boesenbergia rotunda induces apoptosis via mitochondrial disregulation and cytochrome c release in A549 cells in vitro: Involvement of HSP70 and Bcl2/Bax signaling pathways. J Funct Food, 5, 87-97.

Hussain A, Sharma C, Khan S, et al (2015). Aloe vera inhibits proliferation of human breast and cervical cancer cells and acts synergistically with cisplatin. Asian Pac J Cancer Prev, 16, 2939-46.

Jing LJ, Mohamed M, Rahmat A, Bakar MFA (2010). Phytochemicals, antioxidant properties and anticancer investigations of the different parts of several gingers species (Boesenbergia rotunda, Boesenbergia pulchella var. attenuata and Boesenbergia armeniaca). J Med Plants Res, 4, 27-32.

Kamkaen N, Wilkinson JM, Cavanagh HMA (2006). Cytotoxic effect of four Thai edible plants on mammalian cell proliferation. Thai Pharm Health Sci J, 1, 189- 95.

Kementrian Kesehatan RI (2011). Hundred top rang of Indonesian herbal medicine, Kementrian Kesehatan RIBalai Besar Litbang Tanaman Obat dan Obat Tradisional (Indonesian Ministry of Health -Research and Development 

of Herbal Medicine and Traditionally Medicine). 30-1.

Kiat TS, Pippen R, Yusof R, et al (2006). Inhibitory activity of cyclohexenyl chalcone derivatives and flavonoids of fingerroot, Boesenbergia rotunda (L.), towards dengue-2 virus NS3 protease. Bioorg Med Chem Lett, 16, 3337-40.

Kirana C, Jones GP, Record IR, McIntosh GH (2007). Anticancer properties of panduratin A isolated from Boesenbergia cepandurata (Zingiberaceae). J Nat Med, 6, 131- 7.

Lai SL, Cheah SC, Wong PF, et al (2012). In Vitro and In Vivo anti-angiogenic activities of panduratin a. PLOS ONE, 7, 38103.

Le Bail JC, Auborg L, Habrioux G. (2000). Effect of pinostrobin on estrogen metabolism and estrogen receptor transactivation. Cancer Lett, 156, 37-44.

Meiyanto E, Sismindari, Chandra L, Moordiani (2003). Antiproliferative effect of the bark and leaves of Erythrina fuscalour against HeLa cells. Indonesian J Pharm, 14, 124- 31.

Meiyanto E, Susidarti RA, Handayani S, Rahmi F, (2008). Ekstrak etanolik biji buah pinang (Areca catechu 1.) mampu menghambat proliferasi dan memacu apoptosis sel MCF-7. Indonesian J Pharm, 19, 12- 9.

Morikawa T, Funakoshi K, Ninomiya K, et al (2008). Structure of prenylchalcones and prenylflavanones withTNF- $\alpha$ and aminopeptidase $\mathrm{N}$ inhibitory activities from Boesenbergia rotunda. Chem Pharm Bull, 56, 956- 62.

Orlikova B, Tasdemir D, Golais F, et al (2011). Dietary chalcones with chemopreventive and chemotherapeutic potential. Genes Nutr, 6, 125- 47.

Palasap A, Limpaiboon T, Boonsiri P, et al (2014). Cytotoxic effects of phytophenolics from Caesalpinia mimosoides lamk on cervical carcinoma cell lines through an apoptotic pathway. Asian Pac J Cancer Prev, 15, 449- 54.

Rabeta MS, Chan S, Neda DD, et al (2013). Anticancer effect of underutilized fruits. Int Food Res J, 20, 551- 6.

Shindo K, Kato M, Kinoshita A, et al (2006). Analysis of antioxidant anctivities contained in the Boesenbergia pandurata Schult Rhizome. Biosci Biotechnol Biochem, 70, 2281-284.

Tanjung M, Tjahjandarie TS, Sentosa MH (2013). Antioxidant and cytotoxic agent from rhizomes Kaemferia pandurata. Asian Pac J Trop Dis, 3, 401- 4.

Tewtrakul S, Subhadhirasakul S, Karalai C, et al (2009). Antiinflammatory effects of compounds from Kaempferia parviflora and Boesenbergia pandurata. Food Chem, 115, 534-8.

Tuchinda P, Reutrakul V, Claeson P (2002). Anti-cyclohexenyl chalcone derivatives in Boesenbergia pandurata. Phytochemistry, 59, 169- 73.

Yun J, Kwon HJ, Hwang J (2003). In vitro anti-inflammatory activity of panduratin A isolated from Kaempferia pandurata in RAW 264.7 cells. Planta Med, 69, 1102- 8

Yun JM, Kweon MH, Kwon HJ, et al (2006). Induction of apoptosis and cell cycle arrest by a chalcone panduratin a isolated from Kaempferia pandurata in androgenindependent human prostate cancer cells PC3 and DU145. Carcinogenesis, 27, 1454-64 